\title{
アスファルト混合物の流動を伴う領域の 曲げの被壊包絡線に関する研究
}

FAILURE ENVELOPE OF BITUMINOUS MIXTURES

\author{
森 吉 昭 博* - 菅 原 照 雄** \\ By Akihiro MORIYOSHI and Teruo SUGAWARA
}

\section{1. 本研究の意義}

本論文は舗装用アスファルト混合物の曲げの破壊性状 のうち, 特に破壊強度と破壊時のひずみとの関係を種々 の実験結果から論じたものである.

アスファルト混合物の破壊時の性状を研究した例は比 較的少なく, 研究の大部分は破壊強度に関するものであ $り^{1), 2)}$ ，一方破壊時のひずみに関する研究は筆者らのほ かに Heukelom ${ }^{3)}$, Monismith〉 らの研究などごくわず かしかない。

筆者らは最近の研究5),6) から, 破壊強度（または破壞 時のひずみ）と温度との関係を示す曲線はひずみ速度が 変化してもその形状は変化しないこと，また一定ひずみ 速度の破壊強度と破壊時のひずみとの関係は, クリープ 試験から得られたそれと非常によく似ていることを明ら かにし7 99，脆性破壊領域から流動を伴う破壊領域のす ベてにわたり破壊強度と破壊時のひずみとが一定の関係 にある, すなわち破壊包絡線が存在することを示唆して きた10〉,11).

アスファルト混合物の破壊包絡線は混合物の配合設計 を行うときや破壊現象を解析する場合に，きわめて重要 な意味を持つと考えられる. 特に水理構造物にアスファ ルト混合物を使用するときは，その混合物の持つ限界の ひずみ量により，その構造が決定されるといっても過言 ではない. 一方, 世界的にも問題になっているアスファ ルト舖装の低温き裂現象も使用混合物の強度および破壊 時のひずみ量と関係があるといわれていることは暗にア スファルト混合物の破壊包絡線の形状およびその位置が この破壊現象と密接な関係にあることを示している.ま た，通常の舗装にあっても基盤の大変形への追従におい て，大きな意味をもっている。このようにアスファルト

\begin{tabular}{|c|c|c|c|}
\hline 会員 & 工博 & 北海道大学助教授 & 工学部土木工学科 \\
\hline ** 正会員 & 工博 & 北海道大学教授 & 工学部上木工学科 \\
\hline
\end{tabular}

混合物の破壊包絡線の位置やその形状がきわめて重要で あるとされながら，これらが混合物の配合やバインダー 性状により，いかに変化するかはいまだ明確に論じられ ていない.

筆者らのさきに述べた(6),12) 14) アスファルト混合物の 破壞に関する研究は，いずれも温度やひずみ速度がパラ メーターとなっているため，混合物自身のもつ破壊性状 をこれらのパラメーターを介さずに論じようとすると若 干無理な点があった。

本研究では以上の点を考慮し，種々のアスファルト混 合物の破壊包絡線の形状およびその位置が流動を伴う領 域で次のような各種の因子によりいかに変化するかにつ いて論ずることを試みた。

1. 応力履歴

2. 混合物の配合 (バインダー量)

3. バインダーの性状

4. 混合物の空隚率

アスファルト混合物の破壊包絡線は脆性破壊領域から 流動を伴う破壊領域のすべてにわたり存在するが, 前者 の領域では破壊強度や破壊時のひずみの変動係数が後者 の領域よりも著しく大きいため ${ }^{6)}$, 本論文では比較的精 度の良い後者の領域でその 形状や位置について検討し た。

\section{2. 実験, 解析の方法ならびに試料}

本研究では以下のような実験を行った。

$$
\begin{aligned}
& \text { 曲げ試験：供試体寸法 }(\mathrm{cm}) \quad 2.5 \times 2.5 \times 25 \\
& \text { 変位速度 }(\mathrm{mm} / \mathrm{min}) \quad 10 \sim 8000 \\
& \text { 供試体下縁のひずみ速度 }(1 / \mathrm{sec}) \\
& 6.3 \times 10^{-4} \sim 5.0 \times 10^{-1} \\
& \text { 試験温度 }\left({ }^{\circ} \mathrm{C}\right) \quad-15 \sim 25 \\
& \text { a. 一定ひずみ速度試験 }
\end{aligned}
$$


b. 一定ひずみ速度で実験中，急激にひずみ速度 を増加させる試験（以下一段加速ひずみ速度試 験と称す)

c. 一定ひずみ速度で実験中，急激にひずみ速度 を減少させる試験（以下一段減速ひずみ速度試 験之称す）

d. クリープ試験

なお以上の試験のほかに一定ひずみ速度の引張試験, 圧縮試験, 繰り返し曲げおよび圧縮試験, 応力緩和試験 中にある応力レベルに達したとき応力緩和試験を繰り返 し何回も行う，いわゆる繰り返し応力緩和の曲げおよび 圧縮試験なども行ってみた。

一定ひずみ速度の引張試験は，アスファルト混合物の ひずみ量の測定が難しく，破壊包絡線を得ることが困難 であり，現在の段階においてまとまった結論を得るに至 っていない，圧縮の破壊包絡線については機会を得て発 表したいと考えている.あ之の種々の繰り返し試験にお ける結果は興味哚いものであったが，これも現在のとこ ろまとめの段階にまでは至っていない，これらに関して はさらに実験研究を進める必要があろう。

な初本実験に用いた載荷装置はさき汇年, 13) 明らかにし たものとまったく同一なのでここでは省略するが，本研 究のように温度, ひずみ速度をともに広範囲に変化させ た例は他に類をみない。

実験結果の解析はいずれも弾性解を用いた。このた め, 高温かつ低ひずみ速度で行った結果の計算值には当 然多少の誤差が見込まれる。

各試験に抢ける破壊は次の上うに定義した。すなお ち，一定ひずみ速度試験（一段加, 減速ひずみ速度試験 も含む）の破壊は最大荷重点，またクリープ試験でのそ れは第 2 期クリープからはずれる点とした.

使用供試体の作製 法は実験の再現性や 精度に影響を及ぼす 上思わ机るので,で きるかぎり均一なも のが得られるよう努 カし, 特に密度管理 は厳重に行った。曲 げ試験に用いた供試 体の一部 (276 本) の密度のヒストグ ラム党図-1 に示 す.

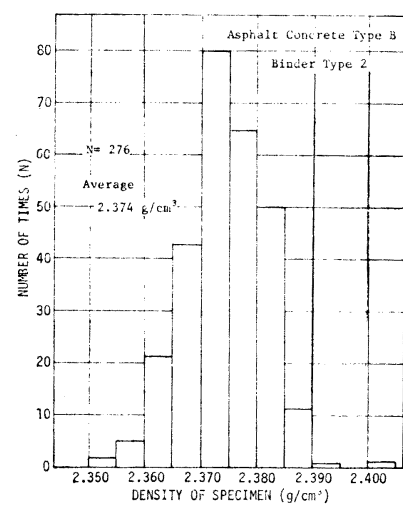

図一1供試体の密度のヒストグラム
実験はすべて Hooke の恒温水槽 (KT-33 型, 設定 温度 $100 \sim-30^{\circ} \mathrm{C}, 0^{\circ} \mathrm{C}$ に扮ける精度 $\left.0.05^{\circ} \mathrm{C}\right)$ の中で 行った.

使用バインダーの主な性状は付表一1に，また使用混 合物の配合は付表一2 亿示寸.

\section{3. 破壞包絡線の形状の確認}

筆者らは曲げ試験における破壊包絡線の形状について 検討するために次のような実験をアスファルトコンクリ 一トタイプBの混合物について行った。

a. 一定ひずみ速度䚾験 変位速度 $(\mathrm{mm} / \mathrm{min}) \quad 5,50,100,300,500$ 供試体下縁のひずみ速度 $(1 / \mathrm{sec})$

$$
\begin{aligned}
& 3.1 \times 10^{-4}, 3.1 \times 10^{-3}, 6.3 \times 10^{-3}, \\
& 1.9 \times 10^{-2}, 3.1 \times 10^{-2}
\end{aligned}
$$

試験温度 $\left({ }^{\circ} \mathrm{C}\right) \quad 5,7.5,10,11,12,13,15$, 20,25

b. クリープ試験

設定応力までの変位速度 $(\mathrm{mm} / \mathrm{min}) 5$

設定応力までのひずみ速度 ( $1 / \mathrm{sec}) \quad 3.1 \times 10^{-4}$ 設定応力 一定ひずみ速度試験に㧈ける破 壊強度の 0.5 および 0.7 倍

試験温度 $\left({ }^{\circ} \mathrm{C}\right) \quad-3,2,5,7,10$

c. 一段加速ひずみ速度試験

初期変位速度 $(\mathrm{mm} / \mathrm{min}) \quad 5,50$

初期ひずみ速度 $(1 / \mathrm{sec}) \quad 3.1 \times 10^{-3}, 3.1 \times 10^{-4}$

最終変位速度 $(\mathrm{mm} / \mathrm{min}) 50,100 ， 500$

最終ひずみ速度 $(1 / \mathrm{sec}) \quad 3.1 \times 10^{-3}, 6.3 \times 10^{-3}$, $3.1 \times 10^{-2}$

ひずみ速度変換点 一定ひずみ速度試験におけ る破壊強度の $0.3,0.5$ 㧈 よび 0.7 倍

試験温度 $\left({ }^{\circ} \mathrm{C}\right) \quad 5,10,15,20,25$

d. 一段減速ひずみ速度試験

初期変位速度 $(\mathrm{mm} / \mathrm{min}) \quad 50$

初期ひずみ速度 $(1 / \mathrm{sec}) \quad 3.1 \times 10^{-3}$

最終変位速度 $(\mathrm{mm} / \mathrm{min}) \quad 5$

最終ひずみ速度 $(1 / \mathrm{sec}) \quad 3.1 \times 10^{-4}$

ひずみ速度変換点一定ひずみ速度試験にお引 る破壊強度の $0.3,0.5$ お よび 0.7 倍

試験温度 $\left({ }^{\circ} \mathrm{C}\right) \quad 10,15$

なおクリープ試験ならびに一段加, 減速ひずみ速度試 験における設定応力およびひずみ速度変換点は一定ひず み速度試験における破壊包絡線の位置から決定した. 
一段加速および減速ひずみ速度試験において，ひずみ 速度の変換点における応力レベルがこれらの応力・ひず み曲線に与える影響について検討した結果は図一2に示 す.いずれの試験も破壊時の強度およびひずみは一定ひ ずみ速度の試験結果とほぼ同一であると考えられる。一 方, 一段加速ひずみ速度試験の応力・ひずみ曲線は一定 ひずみ速度試験におけるそれにすりつくまでにかなり時 間を要するが，これに反し，一段減速ひずみ速度試験に おけるこのすりつきは短時間のうちに終了する.

これらの試験結果と一定ひずみ速度試験の結果を破壊 強度， $\sigma_{b}$ と破壊時のひずみ， $\varepsilon_{b}$ で整理すると図一3 が 得られた.ここに示した曲線は $\sigma_{b}$ と $\varepsilon_{b}$ が, ともに䛊 差を有し両者の重みが等しく, かつ両者の関係が 2 次曲 線で表現できると仮定して整理し得られたものである.

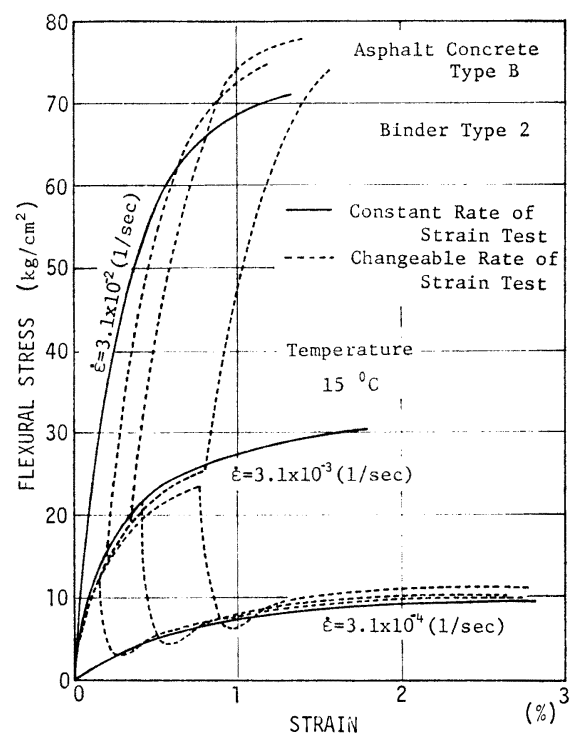

図一2 応力履歷が応力ーひずみ曲線に及ぼす影響

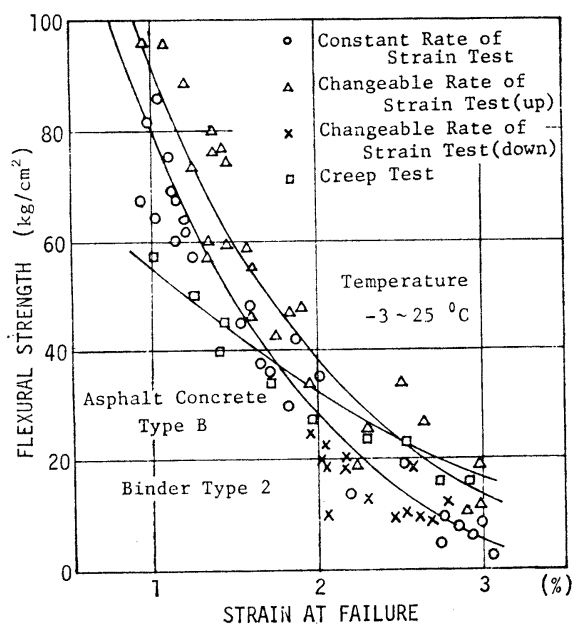

図一3種々の載荷条件下における破壊包絡線の形状
図中に一段減速ひずみ速度試験の結果が示されていない のは実験条件の範囲が狭いため,この整理を行わなかっ たためである.ここで仮定した事項ならびに 2 次曲線の 定数などについてはさらに多くの実験を積重ねることが 必要亡なろう。

以上の条件のもとではクリープ試験から得られた結果 のみが他の試験法から得られた結果とは少し異なってい るように見うけられるので, さらに高応力, 小ひずみ領 域で詳細に検討する必要があると思われるが, 工学的に は種々の実験から得られた破壊包絡線の形状は流動を伴 う領域では応力の履歴に依存せず, いずれもほぼ同一と 考えてもよいと思われる.

曲げの破壊包絡線は流動を伴う破壊領域において, 破 壊強度の減少とともに破壊時のひずみ量は増加するが, 破壊時のひずみにも限界值が存在するように思われる. このためこのひずみを限界ひずみと定義する.

\section{4. 曲げ試験における破壊包絡線}

\section{（1）配合の影響}

図一4 はサンドアスファルト混合物ならびに一般舗装 用混合物について，アスファルト混合物の配合が破壊包 絡線に及ぼす影響について検討したものである.一般舗 装用混合物として連続的骨材粒度組成をもつアスファル トコンクリートタイプAの混合物と不連続な骨材粒度組 成をもつロールドアスファルトタイプAの混合物を採用 した．両者の混合物は粒度組成，バインダー量がともに 異なるが，いずれもマーシャル試験から決定した最適ア スファルト量を含むものである． 2 種の混合物はこのよ うに配合が著しく異なるにもかかわらず破壊包絡線は一

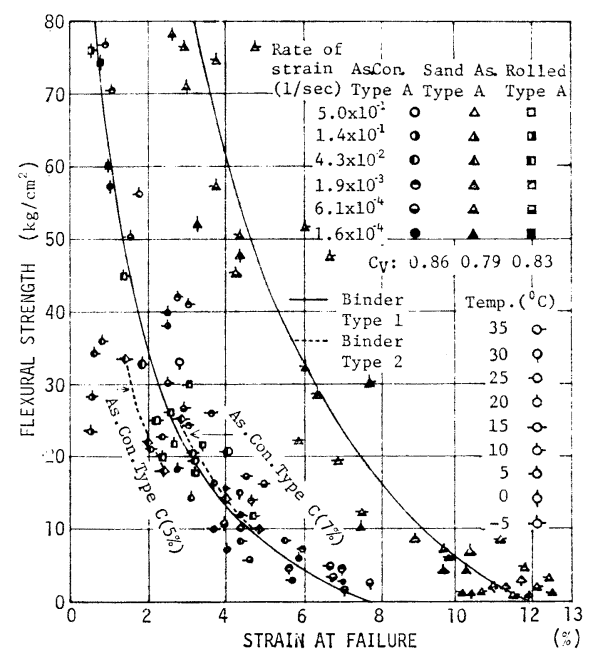

図一4配合が破壊包絡線に及ぼす影響 
本の曲線として表現されるとしてもさしつかえないとい ら注目すべき結果が得られた。

一般舗装用混合物とサンドアスファルトタイプAの混 合物の破壊包絡線を比較すると後者の位置は前者のそれ より破壊強度ならびに破壊時のひずみがともに大きい側 にずれている．この結果, 高応力部での破壊時のひずみ 量はサンドアスファルトタイプAの混合物では前者の約 4 倍, 低応力部では約 1.5 倍となった. 混合物中の骨材 の絶対容積を表現している骨材体積率, $C_{V}$, を両者で比 較すると図一4より約 0.1 の差しかないが，このように 破壊包絡線の形状が 2 種の混合物で異なる原因は骨材最 大粒径の相違やバインダー量の変化により応力の集中や 伝達の状態が著しく変化するためと考えられる.

バインダー量を変化させたときの破壊包絡線は図中に 点線で示されているごとく, バインダー量の増加に伴い 破壊包絡線の位置は破壊強度ならびに破壊時のひずみが ともに大きい側にずれる.

\section{（2）バインダーの性状の影響}

図一5 は 6 種のバインダーを用いたアスファルトコン クリートタイプ Bの混合物について行った曲げ試験の結 果を示す．いずれのバインダーも針入度が 80/100 級で あり, 軟化点も $46.0 \sim 46.5^{\circ} \mathrm{C}$ とほぼ同一で, 原油製法 が異なったものである.な抗これらのバインダーは現在 日本で舗装用として使用されている代表的なものであ る. バインダータイプ 6 を使用した混合物の破壊包絡線 の位置はわずか異なっているらしく思われるが，明確で

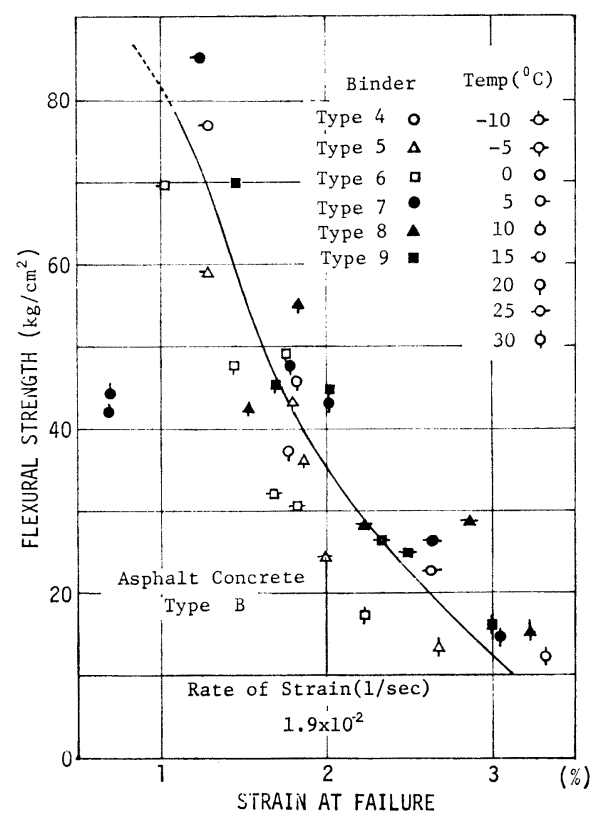

図一5 バインダーの性状が破壊包絡線に及ぼす影響

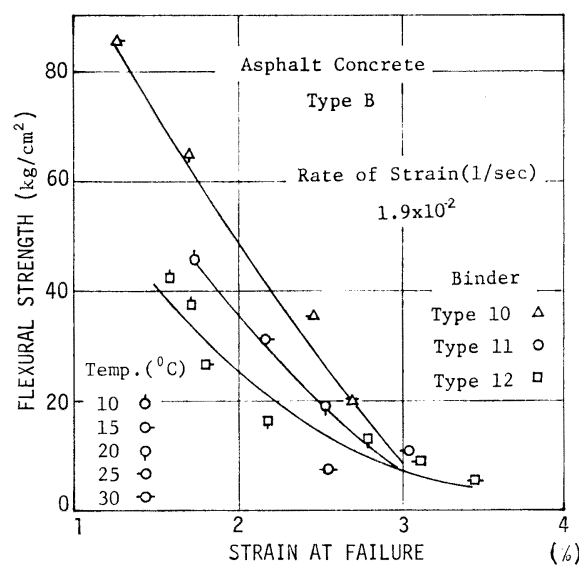

図一6 バインダーの性状が破壊包絡線に及ぼす影響

はなくむしろ 6 種のバインダーを使用した混合物のこれ らの曲線はほぼ同一であると考えてさしつかえないと思 われる。

バインダーの性状で軟化点がほぼ同一で針入度が異な る3 種のバインダーを用いたアスファルト混合物の曲げ 試験の結果は図一6に示す. 針入度指数の小さい（針入 度が小さい）バインダーを使用した混合物の破壊包絡線 の勾配は針入度指数の大きい（針入度が大きい）ものを 使用した破壊包絡線の勾配よりも大きい。またその位置 は高応力部では前者が後者より高応力, 大ひずみ領域に 位置しているが, 低応力部での両者の関係は逆になるこ とが予想される。このような関係は筆者らがすでに述べ

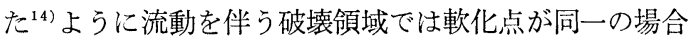
針入度指数の大きなバインダーを使用した混合物ほど破 壊強度・温度曲線ならびに破壞時のひずみ・温度曲線の 勾配が緩やかとなり, 破壊時のひずみの上限值は増加す るといら関係と対応している.

したがってここではバインダーの性状は破壊包絡線の 形状ならびにその位置に無視できない影響を与えている と結論される。

\section{（3）空隙率の影響}

同一の配合でローラコンパクタでの転圧回数を変え, 空偿率が $2.1 \%, 4.0 \%$ および $7.4 \%$ である混合物に ついて空隚率が破壊包絡線の形状に及ぼす影響を検討し 図一7 に示すような結果を得た. 混合物中の空隙率が大 きくなるに伴い，限界ひずみ量も大きくなる傾向が見ら れ, クリープ試験から得られた破壊包絡線と一定ひずみ 速度のそれとはほぼ同一で, その位置は空隙率の大きさ に依存している.このように空隚率の増大に伴い限界ひ ずみ量が増加するのは破壊時のき裂伝播速度が空郘率の 値により異なるためであると考えられる。 


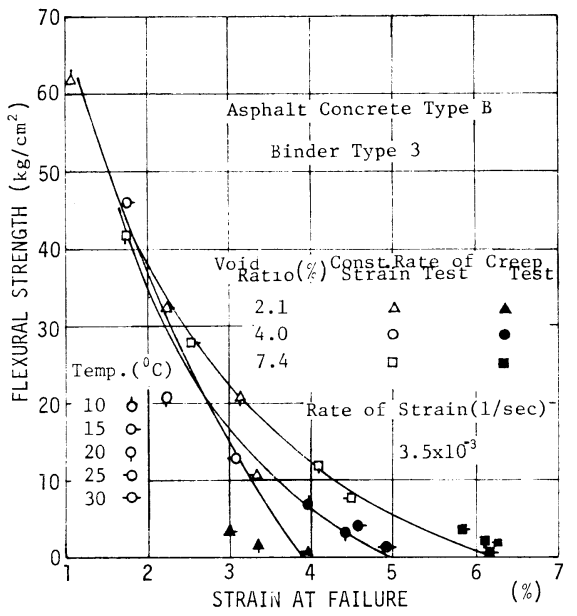

図一7空隙率が破壊包絡線に及ぼす影響

\section{5. 結 論}

曲げ試験の結果から，種々のアスファルト混合物の流 動を伴う領域の破壊包絡線の形状とその位置について, 種々の実験より考察を試みた。ここで得られた主な結論 ま要約すると以下の通りである。

（1）アスファルト混合物の破壊包絡線の形状とその 位置はひずみ速度, 温度および応力履歴に依存せず, 混 合物の配合および空隚率に依存する。

（2）破壊包絡線の位置はバインダー量の増加，軟化 点が同一の場合バインダーの針入度指数の減少，空隚率 の増加に伴い，その形状は少し変化しながらも一般に破 壊強度ならびに破壊時のひずみが大きくなる方向に移動 する。

（3）破壊包絡線の流動を伴う領域の勾配はバインダ 一量の増加，軟化点が同一の場合バインダーの針入度指 数の増加，および空隚率の増加に伴い小さくなる.

付表一1 バインダーの主な性状

\begin{tabular}{|c|c|c|c|c|}
\hline 夕イプ 性 & & 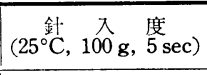 & $\begin{array}{l}\text { 軟 华 点 } \\
\left({ }^{\circ} \mathrm{C}\right)\end{array}$ & $\begin{array}{c}\text { 針入度指数 } \\
\text { P.I. }\end{array}$ \\
\hline タ 1 プ & 1 & 81 & 47.3 & -0.7 \\
\hline 夕 170 & 2 & 96 & 47.0 & -0.3 \\
\hline 夕 $17^{\circ}$ & 3 & 95 & 46.5 & -0.5 \\
\hline 夕 170 & 4 & 96 & 46.5 & -0.5 \\
\hline タ イプ & 5 & 97 & 46.5 & -0.4 \\
\hline タ 170 & 6 & 94 & 46.5 & -0.5 \\
\hline 夕 1 プ & 7 & 95 & 46.0 & -0.6 \\
\hline タイプ & 8 & 91 & 46.0 & -0.8 \\
\hline タ 170 & 9 & 95 & 46.0 & -0.6 \\
\hline タ 1 ブ & 10 & 50 & 51.0 & -1.0 \\
\hline タ 170 & 11 & 120 & 50.5 & 1.5 \\
\hline タイプ & 12 & 147 & 50.0 & 2.1 \\
\hline
\end{tabular}

付表一2 混合物の配合表（\%)

\begin{tabular}{|c|c|c|c|c|c|}
\hline $\begin{array}{l}\text { 混合物の } \\
\text { タイプ } \\
\text { 心るい目 } \\
\text { の開き }(\mathrm{mm}) \\
\end{array}$ & $\begin{array}{l}\text { アスプ } \\
\text { ルトコン } \\
\text { 少 } \\
\text { 行A }\end{array}$ & $\begin{array}{l}\text { アスプ } \\
\text { ルトコン } \\
\text { タリート } \\
\text { タイプB }\end{array}$ & $\begin{array}{l}\text { ザ゚ト } \\
\text { ア ズプ } \\
\text { タイプA }\end{array}$ & $\begin{array}{l}\text { ロールト } \\
\text { アスプ } \\
\text { タトプA }\end{array}$ & $\begin{array}{l}\text { アスプ } \\
\text { ルトコン } \\
\text { 少得 }\end{array}$ \\
\hline 20 & $\ldots$ & - & - & - & 100 \\
\hline 15 & 100 & - & - & 100 & 90 \\
\hline 13 & - & 100 & - & - & $\cdots$ \\
\hline 10 & 84 & 92 & - & 70 & 70 \\
\hline 7 & 74 & 75 & - & 57 & 57 \\
\hline 5 & 65 & 68 & - & 57 & 45 \\
\hline 2.5 & 48 & 47 & 100 & 57 & 30 \\
\hline 1.2 & 36 & 36 & 90 & 57 & 20 \\
\hline 0.6 & 25 & 25 & 80 & 57 & 15 \\
\hline 0.3 & 17 & 14 & 59 & 38 & 15 \\
\hline 0.15 & 12 & 7 & 15 & 20 & 8 \\
\hline 0.074 & 7 & 6 & 11 & 11 & 6 \\
\hline $\begin{array}{c}\text { ハインター量 } \\
(\%)\end{array}$ & 5.7 & 6.0 & 8.5 & 7.2 & $\begin{array}{l}5.0 \\
7.0\end{array}$ \\
\hline
\end{tabular}

以上で述べた本研究の結論はさらに拡張すると強さ・ ひずみ・時間で表現される 3 次元破壊包絡面の設定が可 能であるばかりか, この面からクリープおよび応力緩和 の各性状ならびにこれらと破壊との関係についても論ず ることが可能であると思われるので現在この点について も検討中である。 また圧縮の破壊包絡線に関しては上 島 ${ }^{15)} ら$ が種々の混合物について検討中であるので，いず れ機会を得て発表したいと考えている.

\section{参 考 文 献}

1) Poel C. van der: A General System Describing the Visco-Elastic Properties of Bitumens and its Relation to Routine Test Data, Journal of Applied Chemistry, Vol. 4, Part 5, pp. 221 36, May, 1954.

2) Tons, E. and Krokosky, E.M. : Tensile Properties of Dense, Graded Bituminous Concrete, Proc. Assn. Asphalt Paving Tech. Vol. 32, pp. 497 529, 1963.

3) Heukelom, W. and Klomp, A.J.G. : Dynamic Testing as a Means of Controlling Pavements During and After Construction, Proc. Internat. Conf. on Structural Design of Asphalt Pavements, pp. 667 679, 1962.

4) Monismith, C.L., Secor, G.A. and Secor, K.E. : Temperature Induced Stresses and Deformations in Asphalt Concrete, Proc. Assn. Asphalt Paving Tech. Vol. 34, pp. 248 285, 1965.

5) Teruo Sugawara : Mechanical Response of Bituminous Mixture under Various Loading Conditions, Proc. 3rd Internat. Conf. on Structural Design of Asphalt Pavements, Vol. 1, pp. 343 353, Sept. 1973.

6）森吉昭博・上島 壮・菅原照雄：アスファルト混合物の 破壊強度に関する研究, 土木学会論文報告集, 第 210 号, pp. $57 \sim 64,1973.2$.

7）工藤忠夫・菅原照雄 : 水工用アスファルト混合物のクリ 一プ挙動に関する研究, 土木学会論文報告集, 第 201 号, pp. $113 \sim 122,1972.5$.

8）森吉昭博・吉川 博・菅原照雄：アスフォルト混合物の 空隙率と力学特性, 土木学会第 29 回年次学術講演概要 集, pp. 252 253, 1974. 10.

9）森吉昭博・菅原照雄：種々の載荷条件に打けるアスフォ ルト混合物の曲げ破壊に関する研究, 土木学会北海道支 部論文報告集, pp. $241 \sim 244,1974.2$. 
10）森吉昭博・菅原照雄：アスファルト混合物の曲げ特性に 関する研究，第 7 回複合材料シンポジウム発表報文集， pp. 145 148, 1974. 10.

11）森吉昭博・堀尾哲一郎・堀 秀松：アスファルト混合物 の力学性状におけるバインダーの影響, 土木学会第 28 回 年次学術講演会講演概要集, pp. 233 234, 1973. 10.

12) Teruo Sugawara, Akihiro Moriyoshi, Tsuyoshi Kamijima and Atsushi Kasahara: Failure Behavior of Bituminous Mixtures, Bulletin of the Japan Petroleum Institute, Vol. 17, No. 1, pp. 35 42, April 1975.
13）上島 壮・森吉昭博・营原照雄：アスファルト混合物の 破壊時のひずみに関する研究, 土木学会論文報告集, 第 221 号, pp. 73 80, 1974. 1.

14）营原照雄・上島 壮・森吉昭博：アスフォルト混合物の 低温領域における破壊時のレオロジー挙動, 土木学会論 文報告集, 第 234 号, pp. 131 141，1975．2.

15）上島 壮・沖垣 孝・戸嶋慎一：アスフォルトコンクリー トの一軸圧縮特性について (第 2 報), 土木学会第 29 回 年次学術講演会講演概要集, pp. 256 258, 1974. 10. 